\title{
Utilização de uréia no resíduo desidratado de vitivinícola associado à palma forrageira na alimentação de caprinos: consumo e digestibilidade de nutrientes ${ }^{1}$
}

\section{Manuela Silva Libanio Tosto², Gherman Garcia Leal de Araújo ${ }^{3}$, Ronaldo Lopes Oliveira4, Soraya Maria Palma Luz Jaeger ${ }^{5}$, Daniel Ribeiro Menezes ${ }^{6}$, Fabiana Rodrigues Dantas ${ }^{7}$}

1 Projeto financiado pelo FUNDECI-ETENE/Embrapa.

2 Programa Pós-graduação em Ciência Animal nos Trópicos. Bolsista FAPESO.

${ }^{3}$ Embrapa Semi-Árido, Professor visitante EMV/UFBA.

${ }^{4}$ EMVIUFBA.

5 CCA/UFRB

${ }^{6}$ Programa pós-graduação em Ciência Animal nos Trópicos. Bolsista FAPESB.

7 Programa pós-graduação - UFPB.

RESUMO - Avaliou-se a influência da adição de 0; 0,5; 1 ou 1,5\% de uréia no resíduo desidratado de vitivinícolas - utilizado em associação a palma forrageira na alimentação de caprinos - no consumo e na digestibilidade dos nutrientes. Foram utilizados 24 caprinos machos castrados, sem padrão racial definido, com peso vivo médio de $18 \mathrm{~kg}$, distribuídos em blocos ao acaso, de acordo com o peso vivo. O período experimental foi de 20 dias: 15 para adaptação e 5 para coleta. A adição de teores crescentes de uréia ao resíduo desidratado de vitivinícola possibilitou aumento do consumo de matéria seca (MS), matéria orgânica (MO), proteína bruta (PB) e fibra em detergente neutro (FDN), expressos em kg/dia, \%PV e em g/kgPV,75. Observou-se consumo linear crescente de nutrientes digestíveis totais (NDT), carboidratos totais (CT) e carboidratos não-fibrosos (CNF), em \%PV e g/kgPV ${ }^{0,75}$. Não houve diferença significativa nos consumos de NDT, CT e CNF expressos em kg/dia, cujos valores médios foram 0,363; 0,575 e 0,258, respectivamente. Entretanto, a adição de uréia ao resíduo não influenciou os coeficientes de digestibildade de MS, MO e FDN (médias de 48,13; 46,08 e de 20,37\%, respectivamente). Os coeficientes de digestibilidade de CNF apresentaram crescimento linear, enquanto os de PB apresentaram comportamento quadrático, com valor máximo de 48,93\%, com a adição de 1,3\% de uréia ao resíduo. O uso de uréia no resíduo desidratado de vitivinícola elevou linearmente o consumo de nutrientes, contudo, o nível de 1,3\% é o mais indicado, pois promove melhor digestibilidade da proteína bruta de dietas contendo esse alimento alternativo.

Palavras-chave: cactáceas, caprinocultura, nitrogênio não-protéico, semi-árido, subprodutos agroindustriais

\section{Addition of urea to dehydrated vineyards residue, associated with forage cactus in goats feeding: intake and nutrient digestibility}

\begin{abstract}
The effect of the addition of $0.0,0.5,1.0$ and $1.5 \%$ of urea to dehydrated vineyards residue, associated to forage cactus palm in the feeding of goats on intake and nutrient digestibility was evaluated. Twenty-four castrated crossbred goats, without defined breed, with average $18 \mathrm{~kg}$ of BW were distributed to a randomized block design according to the body weight. The addition of increasing levels of urea to dehydrated vineyards residue increased intakes of dry matter (DM) organic matter (OM), crude protein (CP) and neutral detergent fiber (NDF), in kg/day, \%BW and g/kg BW ${ }^{0.75}$. There was a linear increase intake of total digestible nutrients (TDN), total carbohydrates (TC) and non-fiber carbohydrates (NFC), in $\% \mathrm{BW}$ and $\mathrm{g} / \mathrm{kg} \mathrm{BW}{ }^{0.75}$. There was no difference in the intakes of TDN, TC and NFC, in $\mathrm{kg} /$ day, with means of $0.363,0.575$ and 0.258 , respectively. However, the addition of urea to the residue did not affect the coefficients of digestibility of DM, MO and NDF, with means of 48.13, 46.08 and 20.37\% respectively. The digestibility coefficients NFC showed linear increase, while CP showed quadratic behavior, with maximum at $48.93 \%$, with the addition of $1.3 \%$ of urea to the residue. Use of urea in the dehydrated vineyards residue linearly increased the intake of nutrients, however, the level of $1.3 \%$ is the most appropriate, since promotes better digestibility of the crude protein of the diets containing this alternative feed.
\end{abstract}

Key Words: agrindustrial byproducts, cactus, goat production, non-protein nitrogen, semi-arid

\section{Introdução}

No semi-árido nordestino, as secas periódicas limitam a produção animal, principalmente por reduzir o suprimento de forragens. Apesar dessas limitações, a produção de pequenos ruminantes apresenta números de destaque 
nacional, com aproximadamente 13 milhões de cabeças no rebanho efetivo de caprinos e ovinos (IBGE-SIDRA, 2006), o que a torna uma das mais importantes atividades sócioeconômicas nessa região (Leite \& Vasconcelos, 2000).

A suplementação alimentar, principalmente no período seco, é necessária para melhorar os índices zootécnicos desses rebanhos. A introdução de forrageiras nativas e/ou exóticas adaptadas às condições adversas e a utilização de alimentos alternativos, como os resíduos agroindustriais, possibilita superar essas limitações.

O resíduo desidratado de vitivinícola é uma opção de complementação alimentar para ruminantes, pois apresenta alta concentração de carboidratos fibrosos e teor de proteína bruta próximo de 15\% (base na MS) (Barroso et al., 2006). Contudo, esse resíduo apresenta baixa digestibilidade de nutrientes e baixa disponibilidade de proteína bruta, em virtude dos altos teores de lignina na sua composição. Desta forma, recomenda-se o seu fornecimento em associação a uma fonte de energia (como palma forrageira) e a uma fonte de nitrogênio para atender às exigências nutricionais de mantença e produção animal.

A palma forrageira (Opuntia fícus-indica Mill) é adaptada às condições edafoclimáticas da região e apresenta altas produções de matéria seca por unidade de área. Além disso, é um alimento rico em carboidratos, principalmente não-fibrosos, e possui baixa porcentagem de parede celular, o que a caracteriza como um alimento energético (Melo et al., 2003).

Em ruminantes, quando há oferta suficiente de carboidratos não-fibrosos e digestíveis, a maioria dos microrganismos presentes no rúmen pode sintetizar proteína a partir da amônia. Portanto, podem ser utilizadas fontes de nitrogênio não-protéico (NNP), como a uréia, para suprir deficiências protéicas de animais alimentados com dietas pobres desse nutriente. Fontes de NNP apresentam custos mais baixos por unidade de nitrogênio e são alternativas para substituir, em parte, os tradicionais farelos protéicos.

Objetivou-se avaliar neste estudo os efeitos da adição de uréia no resíduo desidratado de vitivinícola, utilizado em associação a palma forrageira, sobre o consumo e a digestibilidade de nutrientes em caprinos.

\section{Material e Métodos}

O experimento foi realizado nas instalações do setor de Nutrição Animal da Embrapa Semi-Árido, situada em Petrolina, Pernambuco, onde a média pluviométrica anual é de $570 \mathrm{~mm}$ e as temperaturas médias anuais máximas e mínimas são de 33,46 e $20,87^{\circ} \mathrm{C}$, respectivamente. O experi- mento teve duração de 20 dias e foi realizado no mês de abril de 2006.

As dietas, compostas de $63 \%$ de resíduo desidratado de vitivinícola e 37\% de palma forrageira in natura na matéria seca (MS), foram formuladas para atender às exigências de MS de caprinos com $20 \mathrm{~kg}$ de peso vivo e às demandas de 0,90 kg de MS e de 0,50 kg de nutrientes digestíveis totais (NDT) para ganhos de $50 \mathrm{~g} /$ dia, segundo NRC (1981). Os tratamentos foram compostos dos níveis de uréia adicionados ao resíduo desidratado: 0; 0,5; 1 e 1,5\% de uréia (\% na MS do resíduo).

O resíduo doado pela Vitivinícola Milano LTDA é um subproduto do processamento de uva para a produção de vinho, composto basicamente de casca, semente e polpa. Esse resíduo sofreu desidratação ao sol por três dias e teve suas dimensões reduzidas mecanicamente. A palma forrageira foi colhida semanalmente em campo experimental da caatinga e armazenada à sombra, em galpão. Diariamente, durante o período experimental, a palma forrageira foi triturada mecanicamente. A uréia adicionada ao resíduo foi acrescida de enxofre na proporção de 9:1 e homogeneizada ao resíduo, que foi armazenado em tonéis durante todo o período.

Utilizaram-se 24 caprinos sem padrão racial definido (SPRD), castrados, com peso vivo (PV) médio de $18 \mathrm{~kg}$. Antes de iniciar o experimento, os animais foram numerados com brincos, everminados, pesados, sorteados entre os tratamentos e mantidos em gaiolas para estudo de metabolismo contendo cochos para o fornecimento das dietas e de mistura mineral e água à vontade.

Os animais foram distribuídos em delineamento experimental de blocos casualizados, com quatro tratamentos ( 0 ; 0,5; 1 e1,5\% de uréia no resíduo) e seis repetições, considerando o peso vivo o fator de controle.

O período experimental foi de 20 dias: 15 de adaptação ao manejo e aos teores de uréia e 5 de coleta do alimento oferecido, das sobras e das fezes. No período de coleta, foram colocadas sacolas de napa, nos animais, para coleta de fezes. Uma amostra diária de aproximadamente 10\% dos alimentos oferecidos, das sobras e das fezes foi congelada para posterior análise.

A dieta (Tabelas 1 e 2) foi fornecida duas vezes ao dia, às 9 e 15 h, ajustando-se sobra diária de $20 \%$ do oferecido por animal. O resíduo e a palma foram misturados no cocho.

As análises químicas foram realizadas nos Laboratórios de Nutrição Animal da Embrapa Semi-Árido e da Escola de Medicina Veterinária da Universidade Federal da Bahia, segundo metodologia descrita por Silva \& Queiroz (2002).

Os teores de carboidratos totais (CT), carboidratos não-fibrosos (CNF), hemicelulose (HEM) e celulose (CEL) 
foram obtidos pelas equações: $\mathrm{CT}=100-(\mathrm{PB} \%+\mathrm{EE} \%+$ $\mathrm{MM} \%) ; \mathrm{CNF}=100-(\mathrm{PB} \%+\mathrm{EE} \%+\mathrm{MM} \%+\mathrm{FDN} \%) ; \mathrm{HEM}$ $=$ FDN - FDA e CEL $=$ FDA - LIG.

O consumo dos nutrientes foi calculado pela diferença entre o oferecido e as sobras. Os teores de nutrientes digestíveis totais (NDT) das dietas foram calculados pela equação: NDT\% na MS = $(\% \mathrm{~PB} \times \mathrm{CDPB} \%)+2,25(\% \mathrm{EE} \times$ $\mathrm{CDEE} \%)+(\% \mathrm{CT} \times \mathrm{CDCT} \%) / 100$, assim como o consumo de nutrientes digestíveis totais (CNDT), foi calculado pela equação $\mathrm{CNDT}=(\mathrm{CPB}-\mathrm{PBf})+2,25(\mathrm{CEE}-\mathrm{EEf})+(\mathrm{CCT}-$ CTf), em que CPB, CEE e CCT significam, respectivamente,

Tabela 1 - Composição química dos alimentos utilizados nas dietas experimentais

\begin{tabular}{lcc}
\hline \multirow{2}{*}{ Nutriente (\%) } & \multicolumn{2}{c}{ Alimento } \\
\cline { 2 - 3 } & Palma forrageira & $\begin{array}{c}\text { Resíduo de } \\
\text { vitivinícola }\end{array}$ \\
\hline Matéria seca & 7,83 & 85,68 \\
Matéria orgânica & 83,70 & 85,78 \\
Matéria mineral & 16,30 & 14,22 \\
Proteína bruta & 4,83 & 14,19 \\
Extrato etéreo & 0,98 & 6,23 \\
Carboidratos totais & 77,89 & 65,24 \\
Carboidratos não-fibrosos & 50,30 & 21,27 \\
Fibra em detergente neutro ${ }^{1}$ & 29,07 & 43,97 \\
Fibra em detergente ácido ${ }^{1}$ & 25,77 & 35,33 \\
Nitrogênio insolúvel em & 0,20 & 1,04 \\
detergente neutro & & 0,71 \\
Nitrogênio insolúvel em & 0,12 & 8,64 \\
detergente ácido & & 12,46 \\
Hemicelulose & 3,30 & 22,87 \\
Celulose & 21,15 & \\
Lignina & 4,62 & \\
\hline
\end{tabular}

${ }^{1}$ Corrigido para cinzas.

Tabela 2 - Composição química das dietas

\begin{tabular}{lcccc}
\hline Nutriente (\%) & \multicolumn{3}{c}{ Teor de uréia no resíduo (\%MS) } \\
\cline { 2 - 5 } & 0,0 & 0,5 & 1,0 & 1,5 \\
\hline Matéria seca & 56,98 & 56,80 & 56,88 & 56,45 \\
Matéria orgânica & 85,01 & 85,17 & 85,22 & 85,33 \\
Matéria mineral & 14,99 & 14,83 & 14,78 & 14,67 \\
Proteína bruta & 10,74 & 11,32 & 12,98 & 13,77 \\
Extrato etéreo & 4,30 & 3,62 & 3,87 & 3,80 \\
Carboidratos totais & 69,90 & 69,10 & 68,36 & 68,16 \\
Carboidratos não-fibrosos & 31,97 & 31,72 & 31,04 & 30,61 \\
Fibra em detergente neutro ${ }^{1}$ & 38,48 & 37,92 & 37,86 & 38,10 \\
Fibra em detergente ácido ${ }^{1}$ & 31,81 & 32,04 & 31,83 & 33,15 \\
Nitrogênio insolúvel em & 0,73 & 0,65 & 0,73 & 0,70 \\
detergente neutro & & & & \\
Nitrogênio insolúvel em & 0,50 & 0,50 & 0,48 & 0,48 \\
detergente ácido & & & & \\
Hemicelulose & 6,67 & 5,88 & 6,03 & 4,95 \\
Celulose & 15,66 & 17,31 & 16,90 & 16,07 \\
Lignina & 16,14 & 14,73 & 14,93 & 17,08 \\
Nutrientes digestíveis totais & 43,08 & 43,90 & 42,72 & 43,10 \\
\hline
\end{tabular}

${ }^{1}$ Corrigido para cinzas. consumos de PB, EE e CT e PBf, EEf e CTf referem-se aos valores de PB, EE e CT nas fezes (Sniffen et al.,1992).

Os coeficientes de digestibilidade aparente da MS e dos outros nutrientes dos alimentos foram calculados utilizando-se a fórmula:

$\mathrm{CD}=[$ (g de nutriente consumido $-\mathrm{g}$ de nutriente nas fezes $) /(g$ de nutriente consumido $)] \times 100$

Os dados obtidos foram submetidos a análise de variância considerando um delineamento em blocos casualizados utilizando-se o programa estatístico SAS Statistical Analysis System (SAS, 2001). Realizou-se o procedimento GLM, soma de quadrado tipo III (SS3), e estimaram-se as médias ajustadas de quadrados mínimos (LSMEANS), uma vez que houve perda de parcelas. No caso de significância dos teores de uréia sobre as variáveis estudadas, aplicou-se a técnica de regressão polinomial na análise de variância (Pimentel-Gomes, 2002).

\section{Resultados e Discussão}

Todas as dietas avaliadas atenderam às exigências de consumo de matéria seca (CMS) descritas pelo NRC (1981) para caprinos em mantença com $20 \mathrm{~kg}$ de peso vivo (PV), de $0,72 \mathrm{~kg} /$ dia e 3,6\%PV (Tabela 3). Segundo as equações de regressão obtidas, o consumo de MS máximo dos caprinos foi de $0,96 \mathrm{~kg} / \mathrm{dia}$ e ocorreu com a adição de $1,5 \%$ de uréia ao resíduo, ou seja, foi superior ao recomendado (0,90 kg/dia MS) pelo NRC (1981) para ganhos de peso diários de $50 \mathrm{~g} /$ dia.

O consumo de matéria seca (CMS), expresso em kg/dia, \%PV e g/kgPV ${ }^{0,75}$, apresentou comportamento linear com a adição de uréia ao resíduo, o que se deve ao fornecimento de NNP e de carboidratos não-fibrosos presentes na palma. Com maior aporte de amônia e de grupos carbonados para a proliferação dos microrganismos ruminais, ocorre aumento no consumo de MS e fibra, conforme relatado por Valadares Filho et al. (2002).

Esses resultados são similares aos obtidos por Gonzaga Neto et al. (2006), que, ao avaliarem o comportamento ingestivo de nutrientes por caprinos alimentados com capimelefante e cana-de-açúcar associados a uréia como fonte nitrogenada, observaram que os animais alimentados com as dietas contendo maiores teores de uréia apresentaram maior ingestão de alimento, independentemente do volumoso associado. Do mesmo modo, Menezes et al. (2006a) observaram que o consumo de nutrientes por ovinos alimentados com dietas à base de palma forrageira in natura (40\%) e resíduo desidratado de vitivinícola (60\%) associado a uréia $(0,1,2$ e $3 \%)$ apresentaram resposta 
Tabela 3 - Consumo de nutrientes de acordo com os teores de uréia no resíduo desidratado de vitivinícola

\begin{tabular}{|c|c|c|c|c|c|c|c|}
\hline Consumo (kg/dia) & \multicolumn{4}{|c|}{ Teor de uréia no resíduo (\%MS) } & CV (\%) & Regressão & $\mathrm{r}^{2}$ \\
\hline Matéria seca & 0,72 & 0,77 & 0,89 & 0,96 & 14,58 & $\hat{\mathrm{Y}}=0,7131+0,1638 \mathrm{U}^{*}$ & 0,98 \\
\hline Matéria orgânica & 0,61 & 0,66 & 0,75 & 0,82 & 14,98 & $\hat{\mathrm{Y}}=0,6030+0,1414 \mathrm{U}^{*}$ & 0,98 \\
\hline Proteína bruta & 0,07 & 0,08 & 0,11 & 0,13 & 15,73 & $\hat{\mathrm{Y}}=0,0707+0,0392 \mathrm{U}^{* *}$ & 0,97 \\
\hline Fibra em detergente neutro & 0,23 & 0,23 & 0,29 & 0,33 & 16,89 & $\hat{\mathrm{Y}}=0,2133+0,0750 \mathrm{U}^{* *}$ & 0,91 \\
\hline Carbohidratos totais & 0,51 & 0,53 & 0,61 & 0,65 & 19,31 & $\hat{\mathrm{Y}}=0,575^{\mathrm{Ns}}$ & - \\
\hline Carbohidratos não-fibrosos & 0,23 & 0,25 & 0,28 & 0,30 & 15,22 & $\hat{\mathrm{Y}}=0,258 \mathrm{Ns}$ & - \\
\hline \multicolumn{8}{|l|}{ Consumo (\%PV) } \\
\hline Matéria seca & 3,80 & 4,37 & 4,55 & 5,22 & 14,76 & $\hat{\mathrm{Y}}=3,8189+0,8878 \mathrm{U}^{*}$ & 0,96 \\
\hline Fibra em detergente neutro & 1,19 & 1,31 & 1,48 & 1,81 & 17,20 & $\hat{\mathrm{Y}}=1,1438+0,4036 \mathrm{U}^{* *}$ & 0,94 \\
\hline Nutrientes digestíveis totais & 1,66 & 1,91 & 1,97 & 2,24 & 17,65 & $\hat{\mathrm{Y}}=1,6793+0,3562 \mathrm{U}^{*}$ & 0,95 \\
\hline Carbohidratos totais & 2,66 & 3,02 & 3,12 & 3,55 & 14,58 & $\hat{\mathrm{Y}}=2,6759+0,5524 \mathrm{U}^{*}$ & 0,95 \\
\hline Carbohidratos não-fibrosos & 1,22 & 1,41 & 1,50 & 1,64 & 15,88 & $\hat{\mathrm{Y}}=1,24+0,2700 \mathrm{U}^{*}$ & 0,98 \\
\hline \multicolumn{8}{|c|}{ Consumo (g/kg de peso metabólico) } \\
\hline Matéria seca & 79,11 & 89,34 & 95,53 & 107,69 & 14,40 & $\hat{\mathrm{Y}}=79,1298+18,3834 \mathrm{U}^{*}$ & 0,98 \\
\hline Matéria orgânica & 67,04 & 76,12 & 80,81 & 91,73 & 14,53 & $\hat{\mathrm{Y}}=67,1097+15,7544 \mathrm{U}^{*}$ & 0,97 \\
\hline Proteína bruta & 8,09 & 9,80 & 11,96 & 14,90 & 16,70 & $\hat{\mathrm{Y}}=7,8013+4,5170 \mathrm{U}^{* *}$ & 0,98 \\
\hline
\end{tabular}

( ${ }^{*} \mathrm{P}<0,05 ;{ }^{* *} \mathrm{P}<0,01 ; \mathrm{Ns}$ - não-significativo)

quadrática, uma vez que o consumo máximo de MS foi de 2,04 kg/dia e 4,4\% do PV com teor de 2,1\% de uréia na MS da dieta. Esses autores relacionaram esse efeito (aumento no consumo de nutrientes) à interação sincronizada carboidratos solúveis $\times$ nitrogênio não-protéico, o que promove rápida transformação da uréia em amônia e gás carbônico, produtos finais da degradação da proteína de origem alimentar.

Por outro lado, Dantas et al. (2004) forneceram resíduo desidratado de vitivinícola como alimento exclusivo para caprinos e ovinos e registraram consumo de MS de 0,40; 2,59 e 51,53 para caprinos e de 0,45; 2,63 e 53,50 para ovinos, quando expressos em $\mathrm{kg} / \mathrm{dia}$, \%PV e g/kgPV ${ }^{0,75}$, respectivamente. Estes autores não observaram diferença significativa no consumo para as espécies estudadas. Provavelmente, os altos teores de lignina e de fibra presentes no resíduo limitaram o consumo de MS pelo efeito físico de enchimento do rúmen ao ser oferecido como alimento único. Entretanto, neste trabalho, o percentual $37 \%$ de palma forrageira associado aos $63 \%$ de resíduo promoveu consumo de MS 55,56\% superior pelos caprinos em comparação ao trabalho realizado por esses autores. Esses resultados foram favorecidos pelo fornecimento simultâneo de energia (à palma) e de amônia (à uréia), o que contribuiu para a proliferação microbiana e para o aumento no consumo de MS.

O consumo de matéria orgânica (MO), expresso em $\mathrm{kg} / \mathrm{dia}$, \%PV e g/kgPV ${ }^{0,75}$, aumentou linearmente com a adição de NNP ao resíduo, provavelmente em virtude do aumento no consumo de MS, uma vez que as dietas continham teores constantes de matéria orgânica (Tabela 2).

Com os crescentes níveis de uréia, houve aumento nos níveis de proteína da dieta e aumento no consumo de proteína, em g/dia, \%PV e g/kgPV ${ }^{0,75}$. Segundo o NRC (1981), para que caprinos com $20 \mathrm{~kg}$ de peso vivo tenham ganhos de peso diários de 50 g/dia, é necessário consumo 
de 0,069 kg de PB por dia, com base na MS. De acordo com resultados encontrados, a dieta sem adição de uréia fornece a quantidade de PB recomendada pelo NRC (1981) para esses ganhos de peso (Tabela 3).

Barroso et al. (2006) forneceram dietas com $50 \%$ de farelo de palma, $50 \%$ de milho e 1,1\% de uréia para ovinos em confinamento ( $25 \mathrm{~kg}$ de PV) e observaram consumos de PB (0,16 kg/dia) que atenderam às exigências para ganhos de $200 \mathrm{~g} /$ dia (segundo NRC, 1985). Entretanto, Menezes et al. (2006a), ao trabalharem com ovinos em terminação alimentados com dietas à base de resíduo desidratado de vitivinícola, palma forrageira in natura e uréia $(0,1,2$ e $3 \%)$, relataram consumo de $\mathrm{PB}$ para mantença recomendado pelo NRC (1985) com adição de 2,2\% de uréia na MS. Além da faixa de peso (36,9 kg de PV) e de a exigência no consumo de PB (0,18 kg/dia) para os ovinos serem superiores, segundo Van Soest (1987), caprinos são animais de porte baixo, cabeça pequena e boca com lábios móveis e ágeis, o que favorece a escolha das partes mais ricas dos vegetais. Conseqüentemente, ingerem alimentos com maior teor de conteúdo celular e baixa porcentagem de parede celular.

A adição de uréia ao resíduo não influenciou os consumos de NDT, CT e CNF quando avaliados em $\mathrm{kg} / \mathrm{dia}$, cujas médias foram de 0,$363 ; 0,575$ e $0,258 \mathrm{~kg} /$ dia, respectivamente. Contudo, verificou-se aumento linear nos consumos de NDT, CT e CNF quando consumos foram analisados em \%PV e g/kgPV ${ }^{0,75}$ (Tabela 3).

ONRC (1981)recomenda consumo deNDT de $0,400 \mathrm{~kg} / \mathrm{dia}$ e de $0,500 \mathrm{~kg} /$ dia para mantença e ganho de peso de $50 \mathrm{~g} /$ dia, respectivamente, para caprinos com mesma faixa de PV. Apesar de os resultados indicarem que o fornecimento de uréia e palma forrageira propicia o sincronismo entre carboidrato e amônia para os microrganismos ruminais, de modo geral, as dietas possibilitaram baixo aporte de energia para a mantença dos caprinos. Somente com 1,5\% de uréia adicionada ao resíduo, obteve-se consumo de NDT suficiente para atender às exigências de mantença dos animais $(0,410 \mathrm{~kg} / \mathrm{dia})$ (Tabela 3$)$.

Quando calculado em \%PV e g/PV ${ }^{0,75}$, o consumo de NDT apresentou aumento linear, atribuído à adição de uréia. O NRC (1981) recomenda consumo de NDT de 2\%PV e 42,34 g/kgPV ${ }^{0,75}$ para mantença de caprinos com mesma faixa de peso. As necessidades energéticas recomendadas em \%PV e g/kgPV 0,75 para mantença dos caprinos foram atingidas com adição de 0,90\% e 1,02\% de uréia ao resíduo, respectivamente, segundo as equações de regressão obtidas. Ainda assim, não foi atendida a exigência para ganhos de peso de $50 \mathrm{~g} /$ dia, o que está de acordo com resultados obtidos por Barroso et al. (2006), que verificaram déficit de
40\% no consumo de NDT em dietas compostas por resíduo desidratado de vitivinícola (50\%), farelo de palma (50\%) e 1,1\% de uréia para ganho de peso de 200 g/dia em ovinos em confinamento. Esses comportamentos podem estar relacionados aos baixos teores de NDT nas dietas (Tabela 2) e aos altos teores de lignina, que tornaram os carboidratos presentes nas mesmas dietas disponíveis apenas para atender, em parte, às exigências energéticas de mantença dos caprinos.

Uma vez que grande parte das fontes de NNP, como uréia, não contém grupos carbonados, conseqüentemente energia, o aumento linear no consumo de CNF, expresso em \%PV e em g/kgPV ${ }^{0,75}$, relacionado aos crescentes teores de uréia, pode ser explicado pela necessidade dos microrganismos ruminais por fontes de carbono prontamente disponíveis para a síntese de suas proteínas. Esses resultados podem caracterizar a proliferação da população microbiana, o que promove maior necessidade de CNF pelos microrganismos e, conseqüentemente, aumento do consumo de CNF pelo animal.

Resultados semelhantes foram observados por Menezes et al. (2006a), ao avaliarem o consumo de nutrientes em ovinos alimentados com resíduo desidratado de vitivinícola associado a palma forrageira. Esses autores obtiveram resposta quadrática no consumo de CNF e valores máximos de 0,765 kg/dia e 1,66 \%PV para consumo com a adição de $2,1 \%$ de uréia na dieta, fato relacionado ao maior consumo de CNF e à necessidade de carbono pelos microrganismos do rúmen.

O consumo de FDN (kg/dia, \%PV e g/kgPV ${ }^{0,75}$ ) aumentou linearmente com a adição de uréia ao resíduo desidratado. Alguns microrganismos ruminais, como as bactérias celulolíticas, necessitam de nitrogênio proveniente do nitrogênio amoniacal e de grupamentos carbonados para sintetizar suas proteínas (Lucci, 1997). Todavia, neste trabalho, o crescente consumo de FDN pode ter sido determinado pelas características químicas da dieta, visto que os teores de FDN foram constantes e abaixo de $40 \%$. É provável que o alto consumo de FDN observado esteja associado ao aumento do consumo de MS.

Não houve efeito significativo do nível de uréia adicionado ao resíduo sobre a digestibilidade da MS, MO e FDN; as médias observadas foram de 48,13; 46,08 e 20,37\%, respectivamente (Tabela 4). A característica física (partículas reduzidas) e química (teores de FDN inferiores a 45\%) da fibra do resíduo desidratado de vitivinícolas presente na dieta em $63 \%$ pode ter regulado a digestibilidade desses nutrientes.

Outro fator importante é o alto valor de lignina (22,87\%) no resíduo, que também pode ter influenciado a baixa 
Tabela 4 - Coeficiente de digestibilidade dos nutrientes de acordo com os teores de uréia no resíduo desidratado de vitivinícola

\begin{tabular}{|c|c|c|c|c|c|c|c|}
\hline Nutriente (\%) & \multicolumn{4}{|c|}{ Teor de uréia no resíduo(\%MS) } & CV (\%) & Regressão & $\mathrm{r}^{2}$ \\
\hline Matéria seca & 47,4 & 50,1 & 48,4 & 47,1 & 7,0 & $\hat{\mathrm{Y}}=48,13 \mathrm{Ns}$ & - \\
\hline Matéria orgânica & 45,4 & 48,5 & 45,9 & 45,0 & 7,9 & $\hat{\mathrm{Y}}=46,08 \mathrm{Ns}$ & - \\
\hline Proteína bruta & 29,50 & 41,00 & 48,40 & 48,30 & 13,64 & $\hat{\mathrm{Y}}=31,8765+12,9670 \mathrm{U}^{*}$ & 0,87 \\
\hline Carbohidratos não-fibrosos & 84,61 & 86,31 & 85,47 & 91,58 & 3,77 & $\hat{\mathrm{Y}}=83,982+4,014 \mathrm{U}^{* *}$ & 0,68 \\
\hline
\end{tabular}

(* $\mathrm{P}<0,05 ;{ }^{* *} \mathrm{P}<0,01 ; \mathrm{Ns}-$ não-significativo).

MS = matéria seca; $\mathrm{MO}=$ matéria orgânica; $\mathrm{PB}=$ proteína bruta; FDN = fibra em detergente neutro; CNF = carboidratos não-fibrosos

digestibilidade de grande parte dos nutrientes. Grenet \& Besle (1991) relataram que fibras provenientes de células que possuem apenas parede primária são mais susceptíveis a fermentação que aquelas provenientes de células que apresentam parede secundária e/ou lignificadas, que possuem pequenos espaços intracelulares que limitam, além da hidratação, a ação de enzimas bacterianas sobre o substrato.

Baixos coeficientes de digestibilidade também foram encontrados por Barroso et al. (2006), que obtiveram valores de 42,37; 54,95; 41,46 e 32,82\% para os coeficientes de digestibilidade de MS, PB, CT e FDN, respectivamente, em dietas compostas de farelo de palma (50\%) e resíduo desidratado de vitivinícola (50\%) adicionado de 1,1\% de uréia oferecidas a ovinos em terminação. A baixa digestibilidade dos nutrientes avaliados, assim como neste trabalho, foi também atribuída aos altos teores de lignina presentes no resíduo. De forma semelhante, Nörnberg et al. (2002), ao analisarem a composição bromatológica de silagens de bagaço de uva, encontraram coeficientes de digestibilidade in vitro da MS e da MO de 24,55 e 18,66\% respectivamente. Esses autores atribuíram estes baixos valores à presença de tanino e aos teores de lignina (37,48\%) no bagaço de uva. Porém, coeficientes superiores foram

(a)

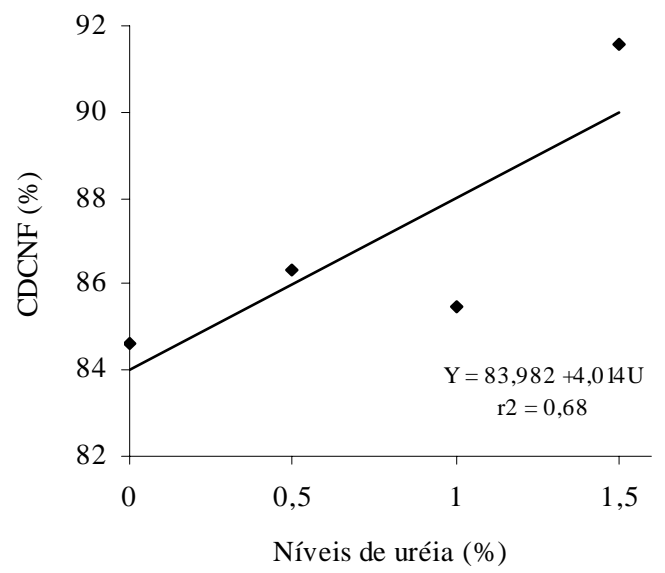

obtidos por Menezes et al. (2006b), ao oferecerem dietas à base de resíduo desidratado de vitivinícola (60\%), palma forrageira in natura e teores crescentes de uréia $(0 ; 1 ; 2$ e $3 \%$ ), encontraram aumento linear da digestibilidade da MS e coeficiente máximo de $62,26 \%$ com a inclusão de 3\% de uréia na dieta. Nas dietas sem adição de uréia, o coeficiente de digestibilidade da MS foi de 54,45\%. Os coeficientes de digestibilidade de PB, CNF e FDN, no entanto, não diferiram e apresentaram média de 85,79; 97,92 e 76,74\%, respectivamente. Provavelmente, os teores mais elevados de uréia adicionados à dieta favoreceram os resultados obtidos por esses autores.

A adição de uréia no resíduo teve efeito linear crescente sobre os coeficientes de digestibilidade dos CNF e efeito quadrático sobre o coeficiente de digestibilidade da PB (Figura 1). Na dieta sem adição de uréia, o coeficiente de digestibilidade da PB foi de 29,50\%. A palma apresenta baixo teor de PB (4,83\%) e esteve presente na dieta somente com 37\% da MS, logo, o teor de proteína proveniente desta forrageira é baixo. O resíduo de vitivinícola (63\% na MS) presente na dieta apresenta teores razoáveis de PB (14,19\%), porém, em virtude da presença de lignina (22,87\%), esta proteína estava pouco disponível, o que resultou em baixos (b)

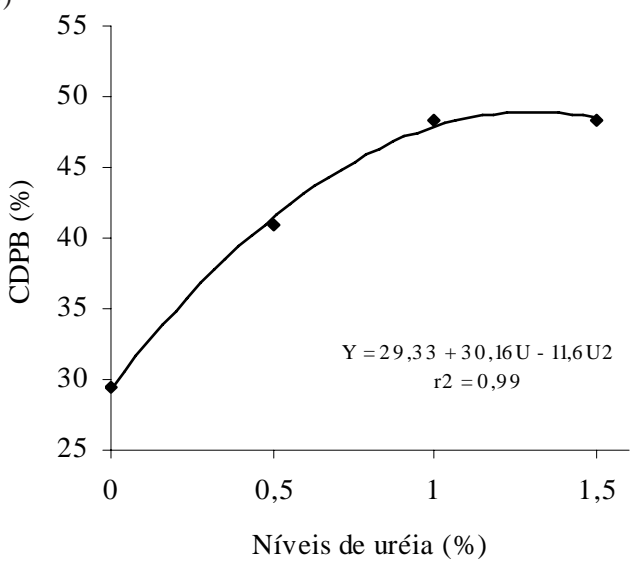

Figura 1 - Coeficiente de digestibilidade (\%) dos carboidratos não-fibrosos (a) e da proteína bruta (b) das dietas experimentais. 
coeficientes de digestibilidade da PB nas dietas sem adição de uréia.

A uréia, no entanto, é solúvel e no rúmen é rapidamente convertida a amônia, o que torna necessário o fornecimento simultâneo de uma fonte de energia prontamente disponível para que os microrganismos utilizem esta amônia à medida que é liberada. Os CNF provenientes da palma forrageira provavelmente foram a fonte de carbono (energia) necessária para a proliferação desses microrganismos e, conseqüentemente, houve aumento na digestibilidade da PB e dos CNF. Entretanto, o coeficiente de digestibilidade da PB alcançou valor máximo de 48,93\% com a adição de 1,3\% de uréia ao resíduo e, a partir de teores superiores de uréia adicionados ao resíduo, foi observado decréscimo no coeficiente de digestibilidade da PB. Provavelmente ocorreu desequilíbrio entre a liberação de amônia e a disponibilidade de carboidratos (energia) presente nas dietas.

\section{Conclusões}

O uso de uréia no resíduo desidratado de vitivinícola elevou linearmente o consumo de nutrientes. Contudo, o nível de 1,3\% de uréia foi considerado o mais indicado, pois promoveu melhor digestibilidade da proteína bruta, o que permite considerar essa dieta uma alternativa estratégica para alimentação de caprinos.

\section{Literatura Citada}

BARROSO, D.D.; ARAÚJO, G.G.L.; SILVA, D.S. et al. Resíduo desidratado de vitivinícolas associado a diferentes fontes energéticas na alimentação de ovinos: consumo e digestibilidade aparente. Ciência e Agrotecnologia, v.30, n.4, p.767-773, 2006.

DANTAS, F.R.; ARAUJO, G.G.L.; CUNHA, A.P. et al. Composição química e consumo de nutrientes do resíduo de uva em caprinos e ovinos, no vale do São Francisco. In: CONGRESSO NORDESTINO DE PRODUÇÃO ANIMAL, 2004, Campina Grande. Anais... Campina Grande: SNPA; UFPB-CCA, 2004. (CD-ROM).

GONZAGA NETO, S.G.; BELTRÃO, F.A.S.; NASCIMENTO, P.G.J. et al. Fontes de volumosos, associadas a níveis de uréia na dieta de cabras em lactação: consumo de nutrientes In: REUNIÃO ANUAL DA SOCIEDADE BRASILEIRA DE ZOOTECNIA, 43., 2006, João Pessoa. Anais... João Pessoa: Sociedade Brasileira de Zootecnia, 2006. (CD-ROM).

GRENET, E.; BESLE, J.M. Microbes and fiber degradation. In: JOUANY, J.P. (Ed.). Rumen microbial metabolism and ruminant digestion. Paris: INRA, 1991. p.107-129.
INSTITUTO BRASILEIRO DE GEOGRAFIA E ESTATISTICA IBGE/SIDRA. Pesquisa pecuária municipal, Sistema IBGE de recuperação automática. Disponível em: <http://www.sidra. ibge.gov.br>. Acesso em: 9/11/2006.

LEITE, E.L.; VASCONCELOS, V.R. Estratégias de alimentação de caprinos e ovinos em pastejo no Nordeste do Brasil. In: SIMPÓSIO NACIONAL SOBRE CAPRINOS E OVINOS DE CORTE, 1., 2000, João Pessoa. Anais... João Pessoa: SINCORTE, 2000. p.71-80.

LUCCI, C.S. Nutrição e manejo de bovinos leiteiros. São Paulo: Manole, 1997. 169p.

MELO, A.A.S.; FERREIRA, M.A.; VERAS, A.S.C. et al. Substituição parcial do farelo de soja por uréia e palma forrageira (Opuntia fícus- indica Mill) em dietas para vacas em lactação: I. Desempenho. Revista Brasileira de Zootecnia, v.32, n.3, p.727-736, 2003.

MENEZES, D.R.; ARAÚJO, G.G.L.; SOCORRO, E.P. et al. Consumo de nutrientes em dietas contendo resíduo desidratado de uva de vitivinícolas associado à palma forrageira "in natura" e diferentes níveis de uréia para ovinos. In: REUNIÃO ANUAL DA SOCIEDADE BRASILEIRA DE ZOOTECNIA, 43., 2006, João Pessoa. Anais... João Pessoa: Sociedade Brasileira de Zootecnia, 2006. (CD-ROM).

MENEZES, D.R.; ARAÚJO, G.G.L.; SOCORRO, E.P. et al. Digestibilidade aparente dos nutrientes em dietas contendo resíduo desidratado de uva de vitivinícolas associado à palma forrageira "in natura" e diferentes níveis de uréia para ovinos. In: REUNIÃO ANUAL DA SOCIEDADE BRASILEIRA DE ZOOTECNIA, 43., 2006, João Pessoa. Anais... João Pessoa: Sociedade Brasileira de Zootecnia, 2006. (CD-ROM).

NATIONAL RESEARCH COUNCIL - NRC. Nutrient requirements of sheep. 6.ed. Washington, D.C.: National Academy of Sciences, 1985. 99p.

NATIONAL RESEARCH COUNCIL - NRC. Nutrient requirements of goats: angora, dairy, and meat goats in temperate and tropical countries. Washington, D.C.: National Academy of Sciences, 1981. 91p. (Nutrient Requirements of Domestic Animals, 15).

NÖRNBERG, J.L.; MELLO, R.O.; FOGAÇA, A. et al. Características química-bromatológicas de silagens de bagaço de uva. In. REUNIÃO ANUAL DA SOCIEDADE BRASILEIRA DE ZOOTECNIA, 39., 2002, Recife. Anais... Recife: Sociedade Brasileira de Zootecnia, 2002. (CD-ROM).

PIMENTEL-GOMES, F.; GARCIA, C.H. Estatística aplicada a experimentos agronômicos e florestais: exposição com exemplos e orientações para uso de aplicativos. Piracicaba: Fundação de Estudos Agrários Luiz de Queiroz, 2002. 309p.

STATISTICAL ANALYSES SYSTEM - SAS. SAS/STAT: user's guide. Version 8.2. Cary: 2001. 943p.

SILVA, D.J.S.; QUEIROZ, A.C. Analise de alimentos: métodos químicos e biológicos. 3.ed. Viçosa, MG: Editora UFV, 2002. 235p.

SNIFFEN, C.J.; OCONNOR, J.D.; Van SOEST, P.J. A net carboydrate and protein sistem for evaluating cattle diets: II. Carbohydrate and protein availability. Journal of Animal Science, v.70, p.3562-3577, 1992.

VALADARES FILHO, S.C.; ROCHA JR., V.R.; CAPELLE, E.R. (Ed.) Tabelas brasileiras de composição de alimentos para bovinos. Viçosa, MG: Universidade Federal de Viçosa, 2002. 297p.

Van SOEST, P.J. Interaction of feeding behavior and forage composition. In: INTERNATIONAL CONFERENCE ON GOATS, 4., 1987, Brasília. Proceedings... Brasília: EMBRAPA, 1987. p.971-987. 